\title{
The Effects of Mind Games and Games Containing Physical Activity on Attention and Visual Perception Levels of Primary School Students
}

\author{
Meryem Altun ${ }^{1}$ \\ ${ }^{1}$ Department Physical Education and Sport Teachers High School, Nigde Omer Halisdemir University, Nigde, \\ Turkey \\ Correspondence: Meryem Altun, Department Physical Education and Sport Teachers High School, Nigde Omer \\ Halisdemir University, Nigde, Turkey. E-mail: mrymltn@hotmail.com
}

Received: September 19, 2019 Accepted: October 11, 2019 Online Published: October 24, 2019

doi:10.5539/jel.v8n6p72 URL: https://doi.org/10.5539/jel.v8n6p72

\begin{abstract}
The aim of the research is to investigate the effects of mind games and games containing physical activity on the attention and visual perception levels of the primary school students. In this research, experimental design with pretest-posttest control group was used. The population of the study consists of seven-year-old children, and the sample consists of 160 volunteer students, who are chosen through purposeful sampling method and involved in game and physical activity group, mind games group, both physical activity and mind games group, and control group, studying at the Primary School in Kırşehir province in the 2017-2018 academic year. The data were collected by "Bourdon Attention Test (Letter Form)" and "Frostig Developmental Visual Perception Test". A 14-week program was applied to the students in the experimental group and the students were given two hours of practice per day for three days a week. In the analysis of the data, arithmetic mean and standard deviation values of the pre-tests were calculated according to the group variables. The dependent sample $t$ test was used to examine the differences of measurements within the group, one-way analysis of variance was used to make comparisons between the groups and the Tukey HSD analysis was used as a post-hoc analysis to determine the difference between the groups. According to the findings of the study, the attention and visual perception pre and post-test scores obtained from the experimental groups indicate that there is a significant difference in favor of the post-test scores. As a result, all experimental groups showed a significantly higher difference in visual perception and attention when compared to the control group. This result shows that applying mind games, games containing physical activity, both mind games and games containing physical activity together are effective in developing visual perception and attention.
\end{abstract}

Keywords: attention, visual perception, mind games, games containing physical activity

\section{Introduction}

Physical activities have an important potential in the student's holistic education. While participating in games and physical activities, students gain opportunities to improve their physical, emotional, social and mental characteristics and to improve their health accordingly (Topkaya, 2012). The general period of sport movements covers the age of 7-8 years. This is a process, in which the behavioral performance of children required for movement and game is expected to increase with the development of their strength, durability, reaction time, movement speed and balance characteristics. Children are interested in all sports branches (Muratl1, 1997).

The desire for raising children as individuals who express themselves freely and who have analytical thinking skills, necessitates the course of games and physical activities. The basic principle of game and physical activities is to provide learning. Children obtain new behaviors or change their behaviors in a positive way as a result of the learning acquired in games and physical activities. Learning games and physical activities is realized through psychomotor behaviors with cognitive basis. Body control and purposeful action are learnable behaviors. Mental procedures related to how and why a movement is made are included in the process of learning. The content of the movement and how it is performed require cognitive procedures. Behavioral changes (learning outcomes) such as enjoying, awareness, being willing to perform the behaviors and sense of achievement, are learning products performed during and after games and physical activities are learning products (Topkaya, 2012).

The aim of education is to open new horizons in the mind of the individual, to make the individual peace with 
the learning and to raise individuals as people who are able to transfer what they have learned into the life. It is the universal aim of education is to make people more competent in terms of psychological, sociological, cognitive, affective and meta cognitive aspects. It is not possible to reach these essential aims of education through classical educational approaches. In order for the education to make the individual to reach the goals, it must be based on experiences and it must establish a personal connection between the individual and the learning subject. The most valid way to establish this connection is to make the student more interested in learning, to turn the moment of learning into a moment of happiness and to make them to gain more concrete experiences (Ulaş, 2014). The individuals will acquire the targeted characteristics through different courses and materials to be used in education. In general, games and in particular, mind games are the means that serve to this aim (Dempsey, Hasey, Lucassen, \& Casey, 2002). Kirriemur and McFarlane (2004) emphasized that the game is vital in the development of skills such as strategic thinking, planning, communication, making practices related to numbers, discussion, making group decision, data processing and Bottino and Ott (2007) asserted that mind games are extremely important in the development of thinking skills, logical reasoning, and strategic thinking. It was stated that games contribute to the behaviors such as increasing motivation (Rosas et al., 2003), increasing attention and concentration (Garris, Ahlers, \& Driskell, 2002), and developing a positive attitude towards learning (Lou, Abrami, \& D'Apollonia, 2001), as well as its contributions to the education. Games always have the power to change our frame of mind. When the games are addressed within the scope of the educational perspective, the games are effective in providing universal and life-changing skills such as "creative thinking, problem solving, analytical thinking, interpretation, communication", which is the target of almost all education programs. Recognizing this effect, the educators have begun to incorporate "mind games" into educational programs. As a result of the studies carried out in this sense in our country, mind games have been accepted as elective courses and it has been one of the courses that is frequently chosen by the students (Gören, 2014).

In the 20th century, rapid and important developments occurred related to how people perceive their own world and how they shape their memories and thoughts. This combination has expanded our knowledge of perception, memory, thinking and processing of information, which means all human cognition. In contrast, the term "perception" covers a higher level of cognition for the interpretation of sensory information. Sensation comprehends the initial detection of the stimulus and perception covers the interpretation of our feelings (Solso, MacLin, \& MacLin, 2014). Studies conducted merely on perception were not sufficient to explain the reason for the expected results. However, important studies related to attention were carried out. The challenges experienced by school-age children in the cognitive fields and majority of their problematic behaviors are related to the attention problem. In the general sense, collecting attention means focusing the attention on a subject consciously. The mental development, age and personal characteristics of the individual play a significant role in this issue. It is effective in attention, recall, problem solving, communication, perception and all other cognitive domains. The skill of attention collection is of great importance in terms of affecting the individual's quality of education and life, and the problems experienced related to this issue are usually noticed when children start primary school. Because the tasks in school life require children to study on a subject for a certain period of time. For this reason, inability to collect attention is an important problem especially in the school years for children, teachers, and parents (Özmen, 2011).

People who have no problems related to the five senses see the same thing, smell the same scent, and hear the same sound. However, the thing that concerns us in the attention and perception is that it is a social and psychological phenomenon and that it can be controlled and guided by external interventions. Starting from this point of view, in this study, the effects of the mind games and games containing physical activity on attention and visual perception levels of primary school students were examined.

\section{Method}

\subsection{Research Model}

In this research, "Experimental Design with Pretest-Posttest Control Group" was used. In experimental design, pre-test measurement for all groups is conducted at the same time. Then experimental process is applied to experimental groups and post-test application is conducted in all groups at the same time (Sönmez \& Alacapınar, 2013).

\subsection{Population and Sampling}

The population of the study consists of seven-year-old children, and the sample consists of 160 volunteer students, who are chosen through purposeful sampling method and involved in game and physical activity group (n: 40), mind games group (n: 40), both physical activity and mind games group (n: 40), and control group (n: 40), studying at the SırrıKardeş Primary School in Kırşehir province in the 2017-2018 academic year. 
Table 1. Distribution of the sample by groups and gender

\begin{tabular}{lllllll}
\hline Groups & Girl & Percentage & Boy & Percentage & Total & Percentage \\
\hline Mind Games Group & 20 & $12.5 \%$ & 20 & $12.5 \%$ & 40 & $25 \%$ \\
Games Containing Physical Activity Group & 20 & $12.5 \%$ & 20 & $12.5 \%$ & 40 & $25 \%$ \\
Mind Games and Games Containing Physical Activity Group & 20 & $12.5 \%$ & 20 & $12.5 \%$ & 40 & $25 \%$ \\
Control Group & 20 & $12.5 \%$ & 20 & $12.5 \%$ & 40 & $25 \%$ \\
Total & 80 & $50 \%$ & 80 & $50 \%$ & 160 & $100 \%$ \\
\hline
\end{tabular}

\subsection{Data Collection Tools}

The data were collected by "Bourdon Attention Test (Letter Form)" and "Frostig Developmental Visual Perception Test". The games containing physical activity were performed in ÜnalKardeş Sports Facility and the mind games were performed in the mind games classroom of the SırrıKardeş Primary School. A 14-week program was applied to the students in the experimental group and the students were given six hours of practice per week for three days a week. In the control group, no study was conducted.

Frostig Developmental Visual Perception Test was adapted by Sökmen (1994). Test-retest reliability was found to be .98 . The correlation between the validity and the motor coordination was found to be .497 . The validity and reliability of the Bourdon Attention Test (Letter Form) is significant at level of .01. (Kaymak, 2003).

\subsection{Data Collection}

The instructions of the test to be applied to each individual separately in a room isolated from excessive stimulants are clearly read. In the Frostig Developmental Visual Perception test, the shapes were first introduced, then the instruction was read and the individual was asked to draw. In the Bourdon Attention test, the individual was asked to mark the letters a, b, d, g in 5 minutes.

\subsection{Analysis of Data}

The obtained data were analyzed by the SPSS 22(Statistic for Social Sciences) Program, after the data were computerized by the researcher. In order to analyze the differences between the measurements within the group, the dependent sample t-test was used and covariance analysis (ANCOVA) was used to compare the groups. The aim of using covariance analysis is to find out how the pre-test findings predict the post-test findings and to leave the effect of the applied experimental method on the post-test scores by checking the effect of it on the post-test after the mathematical model of this relation has been established. In this way, the risk of affecting the post-test application arising from the students saw the tests in the pre-test application was eliminated.

\section{Results}

Table 2. In-group comparison results regarding visual perception

\begin{tabular}{|c|c|c|c|c|c|c|c|}
\hline Groups & Measurements & $\mathbf{N}$ & $\overline{\mathbf{X}}$ & Sd & df & $\mathbf{t}$ & p \\
\hline \multirow[t]{2}{*}{ Mind Games Group } & Visual Perception Pre-Test & 40 & 46.58 & 10.35 & 39 & -14.39 & .00 \\
\hline & Visual Perception Post-Test & 40 & 66.98 & 6.46 & & & \\
\hline Games Containing Physical Activity & Visual Perception Pre-Test & 40 & 54.65 & 8.97 & 39 & -29.35 & .00 \\
\hline Group & Visual Perception Post-Test & 40 & 74.30 & 7.72 & & & \\
\hline Mind Games and Games Containing & Visual Perception Pre-Test & 40 & 52.90 & 7.15 & 39 & -19.86 & .00 \\
\hline Physical Activity Group & Visual Perception Post-Test & 40 & 73.00 & 4.89 & & & \\
\hline \multirow[t]{2}{*}{ Control Group } & Visual Perception Pre-Test & 40 & 48.03 & 4.54 & 39 & -.730 & .460 \\
\hline & Visual Perception Post-Test & 40 & 48.30 & 5.71 & & & \\
\hline
\end{tabular}

According to the results of Dependent Sample t Test applied to determine whether there is a significant difference between the visual perception pre-post test scores obtained from the mind games group, in Table 2, the pre-test mean score was found as $\bar{X}_{\text {pre }}=46.58$ and the post-test mean score was found as $\bar{X}_{\text {post }}=66.9$. The $t$ value $(\mathrm{t}=-14.94)$ obtained related to the difference between the mean scores was found to be significant at .05 level $(\mathrm{p}$ $<.05$ ).

Findings related to the difference between the visual perception pre-test mean score $\left(\overline{\mathrm{X}}_{\mathrm{pre}}=54.65\right)$ and the visual perception post-test mean score $\left(\overline{\mathrm{X}}_{\text {post }}=74.30\right)$ obtained from the game containing physical activity group $(\mathrm{t}=$ $-29.5, \mathrm{p}=.00)$ show a significant difference in .05 significance level. The visual perception pre-test mean score of the mind games and games containing physical activity group was calculated as $\overline{\mathrm{X}}_{\mathrm{pre}}=52.90$ and the post-test 
mean score was calculated as $\overline{\mathrm{X}}_{\text {post }}=73.00$. As a result of the dependent sample $t$ test conducted on the difference between these mean scores, $t$ value was found to be -19.86 . The obtained findings showed that there was a significant difference in favor of the post-test score of the group. The visual perception pre-posttest mean scores of the control group were calculated as $\bar{X}_{\text {pre }}=48.03$ for the pre-test and $\bar{X}_{\text {post }}=48.30$ for the post-test. No significant $(\mathrm{t}=-.730)$ result was found in favor of post-test in comparison of visual perception pre-post test scores.

Table 3. In-group comparison results regarding attention

\begin{tabular}{|c|c|c|c|c|c|c|c|}
\hline Groups & Measurements & $\mathbf{N}$ & $\overline{\mathbf{X}}$ & Sd & df & t & $\mathbf{p}$ \\
\hline \multirow[t]{2}{*}{ Mind Games Group } & Attention Pre-Test & 40 & 52.83 & 22.56 & 39 & -14.61 & .00 \\
\hline & Attention Post-Test & 40 & 89.10 & 17.32 & & & \\
\hline \multirow[t]{2}{*}{ Games Containing Physical Activity Group } & Attention Pre-Test & 40 & 45.05 & 20.02 & 39 & -18.44 & .00 \\
\hline & Attention Post-Test & 40 & 86.28 & 18.26 & & & \\
\hline Mind Games and Games Containing Physical & Attention Pre-Test & 40 & 43.88 & 17.99 & 39 & -26.97 & .00 \\
\hline Activity Group & Attention Post-Test & 40 & 94.13 & 19.01 & & & \\
\hline \multirow[t]{2}{*}{ Control Group } & Attention Pre-Test & 40 & 44.65 & 15.80 & 39 & -1.78 & .080 \\
\hline & Attention Post-Test & 40 & 45.43 & 15.60 & & & \\
\hline
\end{tabular}

According to Table 3, the pre-test mean score of the intelligence games group was calculated as $\bar{X}_{\text {pre }}=52.83$ and the post-test mean score was calculated as $\bar{X}_{\text {post }}=89.10$. As a result of the dependent sample $t$ test conducted on the difference between these mean scores, $t$ value was found to be -14.61 . The obtained findings showed that there was a significant difference in favor of the post-test score of the group. According to the results of Dependent Sample t Test applied to determine whether there is a significant difference between the attention pre-post test scores obtained from thegames containing physical activity group, the pre-test mean score was found as $\bar{X}_{\text {pre }}=45.05$ and the post-test mean score was found as $\bar{X}_{\text {son }}=86.28$. The $t$ value $(t=-18.44)$ obtained related to the difference between the mean scores was found to be significant at .05 level $(p<.05)$.

Mean scores in the Dependent $t$ Test, which was applied to compare the attention pre-post test scores of the mind games and games containing physical activity group, was calculated for the pre-test as $\overline{\mathrm{X}}_{\text {pre }}=43.88$ and for the post-test as $\bar{X}_{\text {post }}=94.13$. In comparison of the pre-test and post-test scores, it was found out that there was a significant difference $(t=-26.97, \mathrm{p}<.05)$ in favor of the post-test. The findings $(t=-1.78)$ related to the difference betweenattention pre-test mean scores $\left(\overline{\mathrm{X}}_{\text {pre }}=44.65\right)$ and Attention Post-Test mean scores $\left(\overline{\mathrm{X}}_{\text {post }}=45.43\right)$ of the control group shows that there is no significant difference.

\section{Findings Related to the Comparison Between Groups}

In order to improve visual perception, a study was conducted on three experimental groups through different methods andno procedure was performed in the control group. The visual perception development of these four groups was investigated by controlling the effect of pretest application. The corrected mean scores of the students obtained through the covariance analysis in accordance with their mean scores of the visual perception scores and the pre-test scores were given in Table 4.

Table 4. Distribution of visual perception score differences by groups

\begin{tabular}{llll}
\hline Group & N & Mean Score & Corrected Mean Score \\
\hline Mind Games & 40 & 66.98 & 69.29 \\
Games Containing Physical Activity & 40 & 74.30 & $\mathbf{7 2 . 0 7}$ \\
Mind Gamesand Games Containing Physical Activity & 40 & 73.00 & 71.74 \\
Control Group & 40 & 64.41 & 56.59 \\
\hline
\end{tabular}

According to the corrected visual perception scores, the most successful method is the Games Containing Physical Activity $(\overline{\mathrm{X}}=72.07)$.

The results of the covariance analyses conducted for testing the significance of the difference between the corrected visual perception scores of the groups were provided in the table below. 
Table 5. Comparison of visual perception post-test scores of the experimental and control groups corrected according to the visual perception pre-test scores

\begin{tabular}{lllllll}
\hline Source of Variance & Sum of Squares & Sd & Square Mean & $\boldsymbol{F}$ & $\boldsymbol{p}$ & $\eta^{2}$ \\
\hline Verified Model & 12688.86 & 4 & 3172.21 & 150.29 & .00 & .80 \\
Breakpoint & 7039.00 & 1 & 7039.00 & 333.48 & .00 & .68 \\
Pre-Test & 3714.74 & 1 & 3714.74 & 175.99 & .00 & .53 \\
Group & 6194.25 & 3 & 2064.75 & 97.82 & .00 & .65 \\
Error & 3271.74 & 155 & 21.11 & & & \\
Total & 742937.00 & 160 & & & & \\
Verified Total & 15960.59 & 159 & & & & \\
\hline
\end{tabular}

As a result of the ANCOVA analysis, it was found that the variance between the visual perception pre-test mean scores and the visual perception post-test mean scores of the experimental and control groups were significant $(\mathrm{F}=$ $150.29, \mathrm{p}=.00, \eta^{2}=.80$ ). The description rate of this variance was determined to be $80 \%$. At the same time, visual perception pre-test mean scores were found to be an important predictor $\left(F=175.99, p=.00, \eta^{2}=.53\right)$ of visual perception post-test mean scores. It was found that the difference between visual perception post-test mean scores corrected according to the visual perception pre-test mean scores were significant $\left(F=97.82, p=.00, \eta^{2}=.65\right)$. According to these findings, it was concluded that the applied experimental methods were effective in increasing the visual perception development of the students.

Bonferroni test was applied to determine which method was more effective in improving visual perception and the results are shown in the table below.

Table 6. Comparison of visual perception post-test scores of the experimental and control groups corrected according to the visual perception pre-test scores

\begin{tabular}{|c|c|c|c|c|}
\hline Group $(I)$ & $\operatorname{Group}(J)$ & Mean Difference (I-J) & Standard Error & $P$ \\
\hline \multirow[t]{4}{*}{ Mind Games } & Games Containing Physical Activity Group & -2.84 & 1.08 & .06 \\
\hline & Mind Games and Games Containing Physical Activity & -2.51 & 1.06 & .11 \\
\hline & Group & & & \\
\hline & Control Group & 12.64 & 1.03 & .00 \\
\hline \multirow{3}{*}{$\begin{array}{l}\text { Games Containing Physical } \\
\text { Activity }\end{array}$} & Mind Games Group & 2.84 & 1.08 & .06 \\
\hline & $\begin{array}{l}\text { Mind Games and Games Containing Physical Activity } \\
\text { Group }\end{array}$ & 0.33 & 1.03 & 1.00 \\
\hline & Control Group & 15.48 & 1.06 & .00 \\
\hline \multirow{4}{*}{$\begin{array}{l}\text { Mind Games and Games } \\
\text { Containing Physical Activity }\end{array}$} & Mind Games Group & 2.51 & 1.06 & .11 \\
\hline & & & & \\
\hline & Games Containing Physical Activity Group & -0.33 & 1.03 & 1.00 \\
\hline & Control Group & 15.15 & 1.04 & .00 \\
\hline \multirow[t]{3}{*}{ Control Group } & Mind Games Group & -12.64 & 1.03 & .00 \\
\hline & Games Containing Physical Activity Group & -15.47 & 1.06 & .00 \\
\hline & $\begin{array}{l}\text { Mind Games and Games Containing Physical Activity } \\
\text { Group }\end{array}$ & -15.15 & 1.04 & .00 \\
\hline
\end{tabular}

The Bonferroni test was used as a Post Hoc test to determine the source of the significant difference that resulted from one-way covariance analysis. It was found in all experimental groups that the difference was significant ( $p$ $<.05$ ) in favor of the experimental group. It is concluded that the most effective method for increasing visual perception development is the Games Containing Physical Activity.

Different methods were used in the experimental group to improve attention and no process was applied in the control group. The attention development of these 4 groups was investigated by controlling the effect of pre-test application. According to the covariance analysis performed for this purpose, attention test mean scores of the students by groups and their mean scores corrected in accordance with the pre-test scores are given in Table 7 . 
Table 7. Distribution of attention score differences by groups

\begin{tabular}{llll}
\hline Group & N & Mean Score & Corrected Mean Score \\
\hline Mind Games & 40 & 89.10 & 84.71 \\
Games Containing Physical Activity & 40 & 86.28 & 87.37 \\
Mind Games and Games Containing Physical Activity & 40 & 94.13 & 96.05 \\
Control Group & 40 & 57.63 & 59.00 \\
\hline
\end{tabular}

According to the corrected attention points, the most successful method is to use the combination of Mind Games and Games Containing Physical Activity $(\overline{\mathrm{X}}=96.05)$.

The results of the covariance analyses performed to test the significance of the difference between the corrected visual perception scores of the groups are given in the table below.

Table 8. Comparison of attention post-test scores of the experimental and control groups corrected according to the attention pre-test scores

\begin{tabular}{lllllll}
\hline Source of Variance & Sum of Squares & Sd & Square Mean & $\boldsymbol{F}$ & $\boldsymbol{p}$ & $\eta^{2}$ \\
\hline Verified Model & 61628.32 & 4.00 & 15407.08 & 111.90 & .00 & 0.74 \\
Breakpoint & 55264.35 & 1.00 & 55264.35 & 401.39 & .00 & 0.72 \\
Pre-Test & 29242.30 & 1.00 & 29242.30 & 212.39 & .00 & 0.58 \\
Group & 30484.10 & 3.00 & 10161.37 & 73.80 & .00 & 0.59 \\
Error & 21341.03 & 155.00 & 137.68 & & & \\
Total & 1153077.00 & 160.00 & & & & \\
Verified Total & 82969.34 & 159.00 & & & & \\
\hline
\end{tabular}

As a result of the ANCOVA analysis, it was found that the variance between the visual perception pre-test mean scores and the visual perception post-test mean scores of the experimental and control groups were significant $(\mathrm{F}=$ $111.90, \mathrm{p}=.00, \eta^{2}=.74$ ). The description rate of this variance was determined to be $74 \%$. At the same time, attention pre-test mean scores were found to be an important predictor $\left(F=212.39, p=.00, \eta^{2}=.58\right)$ of attention post-test mean scores. It was found that the difference between attention post-test mean scores corrected according to the attention pre-test mean scores were significant $\left(F=73.80, p=.00, \eta^{2}=.59\right)$. According to these findings, it was concluded that the applied experimental methods were effective in increasing the attention development of the students.

Bonferroni test was applied to determine which method was more effective in improving attention and the results are shown in the table below.

Table 9. Comparison of visual perception post-test scores of the experimental and control groups corrected according to the attention pre-test scores

\begin{tabular}{|c|c|c|c|c|}
\hline Group $(I)$ & $\operatorname{Group}(J)$ & Mean Difference (I-J) & Standard Error & $\boldsymbol{P}$ \\
\hline \multirow[t]{3}{*}{ Mind Games } & Games Containing Physical Activity Group & -2.663 & 2.65 & 1.00 \\
\hline & $\begin{array}{l}\text { Mind Games and Games Containing Physical } \\
\text { Activity Group }\end{array}$ & $-11.342^{*}$ & 2.66 & .00 \\
\hline & Control Group & $25.705^{*}$ & 2.65 & .00 \\
\hline \multirow{4}{*}{$\begin{array}{l}\text { Games Containing Physical } \\
\text { Activity Group }\end{array}$} & Mind Games & 2.663 & 2.65 & 1.00 \\
\hline & & & & \\
\hline & $\begin{array}{l}\text { Mind Games and Games Containing Physical } \\
\text { Activity Group }\end{array}$ & $-8.679^{*}$ & 2.62 & .01 \\
\hline & Control Group & $28.368^{*}$ & 2.62 & .00 \\
\hline Mind Games and Games & Mind Games & $11.342^{*}$ & 2.66 & .00 \\
\hline \multicolumn{5}{|c|}{ Containing Physical Activity Group } \\
\hline & Games Containing Physical Activity Group & $8.679^{*}$ & 2.62 & .01 \\
\hline & Control Group & $37.047^{*}$ & 2.62 & .00 \\
\hline \multirow[t]{3}{*}{ Control Group } & Mind Games & $-25.705^{*}$ & 2.65 & .00 \\
\hline & Games Containing Physical Activity Group & $-28.368^{*}$ & 2.62 & .00 \\
\hline & $\begin{array}{l}\text { Mind Games and Games Containing Physical } \\
\text { Activity Group }\end{array}$ & $-37.047^{*}$ & 2.62 & .00 \\
\hline
\end{tabular}


The Bonferroni test was used as a Post Hoc test to determine the source of the significant difference that resulted from one-way covariance analysis. It was found that the experimental method applied in all experimental groups was more effective $(p<.05)$ than the control group. In the groups where three different applications were performed, it was observed that the attention development was higher in the group, to which the Mind Games and Physical Activities were applied together, than in the other groups. In other words, the most effective method in attention improvement is to apply the combination of Mind Games and Games Containing Physical Activity.

\section{Discussion}

In this study, the effects of mind games and games containing physical activity on attention and visual perception levels of primary school students have been investigated. Thus, games that require physical activity and various mind games have been used on children and tested whether there is a progress in their levels of attention and visual perception. When the data obtained from the study were examined, there was no difference according to gender in terms of attention and perception levels. This result is thought to be arising from the inability of the seven-age group to fully develop the male and female roles. According to Davies and Parasuraman (1982), attention is mostly affected by the age variable rather than gender (Davies \& Parasuraman cited by Yayc1, 2007). Wagner (1990) stated that a large number of researchers did not mention gender differences in addressing the issue of attention. However, the studies conducted by Kaya (1989); Kaymak (2003); Uskan (2011); Eran and Öztürk (2015) are the other studies supporting the results of this study.

In-group comparisons of visual perception revealed that the groups of mind games, games containing physical activity, and mind games and games containing physical activity were significant at the level of $.05(\mathrm{p}<.05)$. The findings showed that there was a significant difference in favor of the post-test score of the group. It was seen that there was no significant difference between the analysis results applied to compare the visual perception pre-test and post-test scores of the control group.

Çamliyer (1994) examined the effects of movement education on perceptual development levels of children with trainable mental level and determined at the end of the 13-week application that movement education has positive effects on visual perception levels of children with trainable mental level. Akaroğlu and Dereli (2012) aimed to reveal the effect of visual perception education given by educational toys on the visual perception skills of children and they provide training to the experimental group with the educational toys produced for the visual perception education throughout 14 weeks, for 3 days per week with 35-45 minutes' sessions. As a result of the research, it was determined that visual perception education program given by educational toys increased children's Frostig developmental visual perception subtest scores and after a one-year of follow-up study, they found that the effect of the applied training program was continuous. Memiş and Harmankaya (2012) aimed to determine the visual perception levels of children in the first grade and as a result of their research, they determined that the visual perception skills of the children who received pre-school education were better. This result explains the higher scores of control group in terms of revealing the effect of Preschool Education Program on visual perception skills of children. It is thought to be arisen from the widespread use of education through game in preschool education institutions.

According to the in-group comparisons related toattention, it was seen that the groups of mind games, games containing physical activity, and mind games and games containing physical activity were significant at the level of $.05(\mathrm{p}<.05)$. The findings showed that there was a significant difference in favor of the post-test score of the group. The findings related to the difference between the attention pre-test and post-test mean scores obtained from the control group was not found statistically significant.

According to the results of the study "Investigation of the Effects of Brain Teasers on Attention Spans of Pre-School Children" conducted by Altun et al. (2016), it was seen that there was a significant difference between the attention levels of the six years old children who were trained with the Mind Games and who were trained according to the Ministry of National Education Preschool Education Program in favor of the experimental group. This result shows that mind games are effective in improving the level of attention.

In a study of Gözalan (2013), in which the effect of the game-based attention education program on the attention and language skills of the 5-6-year-old children, a significant difference was found between pre-post test scores of the children in the control group according to $\mathrm{P}<0.01$ significance level. It is seen that there is a difference between the pre and post-test mean scores of the children in the control group, but this difference is higher in the children involved in the experimental group. $<$ Control group $(30.93$ - 29.00 =1.93); Experimental group (35.80 $28.93=6.87)>$ It was thought that the children in the control group who did not attend the "Game-Based Attention Education Program" could have been affected by the education of the school in that time, and therefore, this development in the attention skills of the children in the control group was a natural result. 
According to the result of the study conducted by Yurdakul et al. (2012), in which the effects of movement education on attention and memory development in eight-year-old children was examined, the pre and post-test differences of both the experimental group and the control group were statistically significant. The results obtained from the control group were based on two main reasons: First, the 8-year-old child is naturally growing and developing. The development of the child in any environment suitable for development continues under all circumstances. The mission of the school is to form the basis for this development. Even if the child does not go to school, this development occurs. However, the effect of the growth and development process can lead to different results in different environments. It was stated that the pre and post-test differences in the control group may be related to this. According to this, the findings of the research and the findings obtained from the literature review do not correspond to each other.

When the analysis results of the comparisons between the groups were examined, it was concluded that the difference between the groups in that visual perception and attention posttest scores was significant. When the analysis results, which was applied to determine the difference between the groups, were examined, all experimental groups showed a significant higher difference in the development of visual perception than the control group. In the general sense, the application of both mind games and physical activity cards was the most successful experimental method to improve visual perception.

When the results of the analysis on the post-test scores were examined, it was seen that all experimental groups had significantly higher results than the control group. When the findings obtained from the experimental groups were examined, it was concluded that the attention post-test mean scores of the students in the experimental group, to whom both mind games and physical activity cards were applied, were higher than the mean scores of the students in the control group, but the difference was not significant.

Through the studies conducted on normal children, Joan Reynell (1977) revealed that there were certain periods in the normal development process for attention control and that the level of attention changed at each period (Dönmez et al., 1981). In a study on the relationship between movement education and attention and memory development in eight-year-old children Akcinlı (2005) found that movement education has a positive effect on attention and memory development. In the study of Topçu et al. (2007), in which the effect of folklore exercise on children with attention deficit hyperactivity disorder was examined, it was stated that children's attention deficit, hyperactive and impulsive behaviors were decreased in the children with attention deficit hyperactivity disorder both at home and at school through regular folklore exercise. In the study, in which the effect of use of educational games in physical education course on the attention level of children is examined, conducted by Akandere et al. (2010), it was determined that the educational game program applied to 9-13 age group students for 8 weeks had an effect on the attention level and that the attention values of the experimental group, to which educational game program was applied, were higher than the values of the control group. In a study conducted by Adsiz (2010) on examining the effect of doing regular sports on the attention of primary school students, according to the findings obtained from the primary school students, it was determined through the tests that the ones who did sports were $83 \%$ more careful than those who did not do sports. The results obtained from these studies are interpreted as necessary developments can be provided to those participating in activities for movement and sports training.

Uskan (2011) stated in his study, in which the effectiveness of a program designed for develop the attention skills of the 8-10-year-old children with attention deficit disorder was tested, that there was a positive change in children with game techniques. According to the study of Asan (2011), conducted in order to examine the attention levels of children playing table tennis, it was observed that table tennis exercises had a positive effect on attention characteristics in 9-13 age group children. In the study of Yurdakul et al. (2012) conducted on effects of movement education on attention and memory development of the eight-year-old children, in addition to the standard education and training activities, a game-based movement education program, which was thought to improve the attention and memory, was applied to the experimental group in the physical education classes (2 lessons per week) by the researcher for 12 weeks under the supervision of class teachers. Based on the findings obtained from the statistical data, it was stated that specially prepared movement training program was effective on the attention and memory development of 8-year-old primary school students. According to the findings of the study conducted on a pair of 32 siblings by Benigno and Farrar (2012), it was concluded that the games played through sibling games affected the attention development of the children.

According to the study of Tunç (2013), which was conducted to investigate the attention levels of 14-15 age group students, it was observed that regular golf exercises had a positive effect on attention characteristics of the 14-15 age group children. According to the results of Gözalan (2013), the post-test scores of the children in experimental group are significantly higher than their pre-test scores. This result shows that the applied 
Game-Based Attention Training Program has an effect on children's attention skills. In the study of Pişkin (2015), in which the effect of attention collection education on the attention collection skills of the second-grade students examined by using the Bourdon Attention Test, he applied various activities and games. As a result of the study, it was determined that attention collection education provided to children was effective in developing children's attention collection skills.

According to the study of Dağdelen and Kösterelioğlu (2015) related to evaluation of games and physical activity course in primary schools in accordance with the opinions of the teacher, it is thought that the course develops students in many aspects. Practices in the course address the student development from a holistic perspective. It was stated that the course is a game-based course and that the game is a very important activity for children. The views of the teachers in the interviews also reflected this fact.In this respect, it is argued that the more the course of games and physical activities are considered as important and carried out in a planned manner under the control of the teachers, the more the learning outcomes will be permanent and that the course of games and physical activities has a significant place in the holistic development of the students.

As a result, it has been found that the most effective experimental method to increase the visual perception development applied to the groups is the method of combining mind games and games containing physical activity.

The studies conducted upon the literature review have been formed by applying attention-enhancing programs on the preschoolers with mental disability, $\mathrm{CP}$, trainable mental disability and the visual perception programs have been formed based on shapes. It has been aimed to draw attention to the fact that the studies on this subject are mostly focused on children with attention deficit and hyperactivity disorder and there are not sufficient studies about children, who have improvable attention problems, or normal children by using games containing physical activity and mind games.

\section{References}

Adsız, E. (2010). İlköğretim çağındaki öğrencilerde düzenli yapılan sporun dikkat üzerin eetkisinin araştırllması. Yüksek Lisans Tezi. Ege Üniversitesi Sağlık Bilimleri Enstitüsü, İzmir. No: 298898.

Akandere, M., Baştuğ, G., Asan, R., Baştuğ, K. (21-23 May 2010). Çocuklarda eğitsel oyunun dikkat üzerine etkisi. International Scientific Conference 'Perspectives in Physical Education and Spor, Constanta, Romania.

Akaroğlu, E. G., \& Dereli, E. (2012). Okul öncesi çocukların görsel algı eğitimlerine yönelik geliştirilmiş eğitici oyuncakların çocukların görsel algılarına etkisi. Journal of World of Turks, 4(1), 201-222.

Akcınlı, N. (2005). Sekiz yaş grubu çocuklarda hareket eğitimi ile dikkat ve hafiza gelişiminin ilişkisi. Yüksek Lisans Tezi, Celal Bayar Üniversitesi Sağlık Bilimleri Enstitüsü, Manisa.

Altun, M., Hazar, M., \& Hazar, Z. (2016). Investigation of the effects of brain teasers on attention spans of pre-school children. International Journal of Environmental \& Sclence Education, 11(15), 8112-8119.

Asan, R. (2011). Sekiz haftalı masa tenisi egzersizinin 9-13 yaş arası çocuklarda dikkat üzerine etkisi. Yüksek Lisans Tezi. SelçukÜniversitesi Sağlık Bilimleri Enstitüsü, Konya.

Benıgno, J. P., \& Farrar, M. J. (2012). Determinants of Joint Attention in Young Siblings' Play, Infant and Child Development Inf. Child. Dev. 21. Published online 31 August 2016 in Wiley Online Library. https://doi.org/10.1002/icd.743

Bottino, R. M., \& Ott, M. (2006). Mind games, reasoning skills, and the primary school curriculum: Hints from a field experiment. Learning Media \& Technology, 31(4), 359-375. https://doi.org/10.1080/17439880601022981

Çamlıyer, H. (1994). Eğitilebilir zekâd üzeyindeki çocuklarda hareket eğitiminin algısal gelişim düzeylerine etkileri. DoktoraTezi, DokuzEylül Üniversitesi Sağlık Bilimleri Enstitüsü, İzmir.

Dağdelen, O., \& Kösterelioğlu, İ. (2015). İlkokullardaki oyun ve fiziki etkinlikler dersinin öğretmen görüşlerine göre değerlendirilmesi. Adlyaman Üniversitesi Sosyal Bilimler Enstitüsü Dergisi, 8(19), 97-128. https://doi.org/10.14520/adyusbd.35272

Dempsey, J. V., Haynes, L. L., Lucassen, B. A., \& Casey, M. S. (2002). Forty simple computer games and what they could mean to educators. Simulation and Gaming, 33(2), 157-168. https://doi.org/10.1177/1046878102332003

Dönmez, N. B., Abidoğlu, Ü., Dinçer, Ç., Erdemir, N., \& Gümüşçü, S. (1981). Okulöncesi dönemde dilgelişimi 
etkinlikleri (3. Bask1). İstanbul: Ya-Pa.

Eran, N., \& Öztürk, A. (08-10 Haziran 2015). Okulöncesi çocuklarında görsel ögrrenme ve dikkat becerisine yönelik geliştirilmiş oyuncaklarda eğitim almış ile almamış çocukların görsel algılama düzeylerindeki etkisi (pp. 686-689). Hacettepe Üniversitesi, EJER Congress Conference Proceedings, Ankara: An1.

Gören, E. (2014). Zekaoyunları. İstanbul: Favori.

Gözalan, E. (2013). Oyun temelli dikkat eğitim programının 5-6 yaş çocuklarının dikkat ve dil becerilerine etkisinin incelenmesi. Yüksek Lisans Tezi. Selçuk Üniversitesi Sosya 1Bilimler Enstitüsü. Konya. https://doi.org/10.18493/kmusekad.12328

Kaya, Ö. (1989). Frostig görsel algılama eğitim programının anaokulu çocuklarının görsel algılama ve zihinsel gelişmelerine etkisi. Yüksek Lisans Tezi. Hacettepe Üniversitesi Sağlık Bilimleri Enstitüsü, Ankara.

Kaymak, S. (2003). Dikkat toplama eğitimi programınıni lköğretim 2.ve 3. sınıf ögrrencilerinin dikkat toplama becerilerinin gelişstirilmesine etkisi. Doktora Tezi, Ankara Üniversitesi Sosya 1Bilimler Enstitüsü, Ankara.

Kirriemuir, J., \& McFarlane, A. (2004). Literature Review in Games and Learning (Report 8, Futurelab series). Retrieved from http://admin.futurelab.org.uk/resources/documents/lit_reviews/Games_Review.pdf

Lou, Y., Abrami, P., \& D'Apollonia, S. (2001). Small group and individual learning with technology: A meta-analysis. Review of Educational Research, 71(3), 449-521. https://doi.org/10.3102/00346543071003449

Memiş, A., \& Harmankaya, T. (2012). İlköğretim okulu birinci sınıf öğrencilerinin görselalgı düzeyleri. TSA, 16(1), 27-46.

Muratl1, S. (1997). Çocuk ve spor. Ankara: Bağırgan.

Özmen, S. K. (2011). Dikkat toplama becerisini geliştirici etkinlikler, ilköğretim 1. 2. 3. sınıf. (4. Baskı). Ankara: An1.

Özmen, S. K. (2011a). Dikkat eksikliği hiperaktivite bozukluğu'nda çok yönlü eğitimu ygulamalarının etkisi. Eğitim ve Bilim, 36(161), 256-270.

Rosas, R., Nussbaum, M., Cumsille, P., Marianov, V., Correa, M., Flores, P., ... Salinas, M. (2003). Beyond Nintendo: design and assessment of educational video games for first and second grade students. Computer \& Education, 40(1), 71-94. https://doi.org/10.1016/S0360-1315(02)00099-4

Sökmen, S. (1994). Frostig görsel algı testi geçerlik ve güvenirlik çalışması. Yüksek Lisans Tezi, Marmara Üniversitesi Sosyal Bilimler Enstitüsü, İstanbul.

Solso, R. L., MacLin, M. K., \& MacLin, O. H. (2014). Bilişssel psikoloji (A. Ayçiçeği-Dinn, Çev.). İstanbul: Kitabevi.

Sönmez, V., \& Alacapınar, F. G. (2013). Örneklendirilmiş Bilimsel Araştırma Yöntemleri. Ankara: Anı Yayincilik.

Topçu, B., Yıldız, S., \& Bilgen, Z. T. (2007). Dikkat eksikliği hiperaktivite bozukluğu olan çocuklarda folklor egzersizinin etkisi. Genel Tip Derg, 17(2), 89-93.

Topkaya, İ. (2012). Illkokullarda “Oyun ve Fiziki Etkinlikler” dersi öğretimi. İstanbul: Kriter.

Tunç, A. (2013). Golf sporu yapan çocukların dikkat düzeylerinin incelenmesi. Yüksek Lisans Tezi. Selçuk Üniversitesi Sağlık Bilimleri Enstitüsü, Konya.

Ulaş, H. (2014). Drama, oyun ve fiziki etkinlikler. İ stanbul: Favori.

Uskan, C. (2011). Dikkat eksikliği bozukluğu olan 8-10 yaşındaki çocukların dikkat becerilerini geliştirmeye dayalı bir programın etkililiğinin sinanması. Yüksek Lisans Tezi. Maltepe Üniversitesi Sosyal Bilimler Enstitüsü, İstanbul.

Wagner, H. L. (1990). The Spontaneous facial expressions of differential pozitive and negative emotions. Motivations and Emotions, 14(1), 27-43. https://doi.org/10.1016/S0360-1315(02)00099-4

Yaycı, L. (2007). İlköğretim dördüncü sınıf öğrencilerinde seçici ve yoğunlaş̧tırlmış dikkat becerilerini gelişstirmeye dayalı bir programın etkililiğinin sinanmast. Doktora Tezi, Marmara Üniversitesi Eğitim Bilimleri Enstitüsü, İstanbul.

Yurdakul, N. A., Çamlıyer, H., Çamlıyer, H., Karabulut N., \& Soytürk, M. (2012). Sekiz yaş grubu çocuklarda hareket eğitiminin dikkat ve hafıza gelişimine etkileri. Selçuk Üniversitesi Beden Eğitimi ve Spor Bilim 
Dergisi, 14(1), 103-108.

\section{Copyrights}

Copyright for this article is retained by the author, with first publication rights granted to the journal.

This is an open-access article distributed under the terms and conditions of the Creative Commons Attribution license (http://creativecommons.org/licenses/by/4.0/). 